\title{
PERANCANGAN APLIKASI PENGOLAHAN DATA RAWAT INAP MENGGUNAKAN PEMOGRAMAN BERBASIS JAVA PADA UPTD PUSKESMAS BATANGHARI LAMPUNG TIMUR
}

\author{
Dedi Irawan ${ }^{(1)}$ Pujianto ${ }^{(2)}$ \\ Prodi S1 Ilmu Komputer, Fakultas Ilmu Komputer \\ Universitas Muhammadiyah Metro \\ Jl. KH. Dewantara No.116 Iring Mulyo Metro, Kota Metro Lampung \\ e-mail: dedi.mti@gmail.com
}

\begin{abstract}
ABSTRAK
Tujuan pembuatan aplikasi pengolahan data rawat inap pada UPTD Puskesmas Batanghari Lampung Timur. Masalah yang didapat adalah pengolahan data rawat inap, dan juga laporan bulanan data pasien masih menggunakan buku buku besar dan. Selain itu pencarian data pasien yang membutuhkan waktu lama karena harus mencari di buku pencatatan. Dalam penelitian menggunakan metode berupa pengamatan, wawancara, dokumentasi dan studi pustaka. Sedangkan Program yang dibuat menggunakan bahasa pemrograman Java, Pembuatan pencarian pasien rawat inap dan laporan rawat inap menggunakan IReports. Berdasarkan hasil penelitian, aplikasi pengolahan data pasien rawat inap pada UPTD Puskesmas Batanghari menggunakan bahasa pemrograman Java dengan databese MySQL, Telah menghasilan pengolahan data rawat inap dan pencarian pada data rawat inap UPTD Puskesmas Batanghari, dan mempermudah pembuatan laporan rawat inap perbulan di UPTD Puskesmas Batanghari Lampung Timur.
\end{abstract}

Kata Kunci: Perancangan pada UPTD Puskesmas Batanghari Lampung Timur, Aplikasi pengolahan data rawat inap, Laporan rawat inap.

\section{PENDAHULUAN}

Di dalam kehidupan masyarakat yang terus menerus berkembang, pelayanan kesehatan merupakan salah satu bentuk di dalam mewujudkan kesejahteraan masyarakat, tetapi dalam pelayanannya masih saja mengalami penurunan kinerja. Untuk itu diperlukan suatu terobosan baru dalam bidang kesehatan ini yang dapat meringankan kinerja dari suatu pelayanan kesehatan dalam melayani masyarakat. Namun saat ini, banyak masalah yang dihadapi puskesmas dalam memberikan informasi yang akurat dan pelayanan yang cepat serta memuaskan pasien. Oleh sebab itu, diperlukan suatu teknologi baru yang dapat digunakan untuk memenuhi informasi yang efektif bagi pasien dan pihak manajemen. Dengan perkembangan tersebut, maka proses pengelolaan sistem informasi melalui sistem komputerisasi mampu menghasilkan kinerja yang lebih baik. Hal tersebut dipengaruhi oleh kecepatan, ketepatan maupun keamanan suatu informasi yang dikelola melalui sistem komputerisasi sehingga mampu bekerja dengan baik. Saat ini peran informasi sangat penting dalam menunjang berbagai kegiatan khususnya peran informasi dalam dunia kesehatan. Dalam menyajikan informasi yang aktual dan akurat, peran komputer sangat mutlak dibutuhkan, Khususnya berkaitan denngan puskesmas. Teknologi Informasi telah mengubah manusia dalam segala aspek kehidupan, seperti pada saat penyimpanan data, pengolahan data serta pencarian informasi, secara tidak langsung dapat dikatakan semua serba terkomputerisasi. 


\section{JIKI}

Pengolahan Data di Puskesmas Batanghari Lampung Timur merupakan salah satu komponen yang penting dalam mewujudkan suatu sistem informasi di Puskesmas. Pengolahan data secara manual, mempunyai banyak kelemahan, selain membutuhkan waktu yang lama keakurasian data juga kurang dapat di terima karna kemungkinan kesalahan sangat besar. Dengan dukungan teknologi informasi yang akan di buat, diharapkaan pekerjaan pengelolaan data dapat di gantikan oleh suatu sistem informasi dengan menggunakan komputer. Puskesmas adalah Unit Pelayanan Teknis Dinas (UPTD) Kesehatan Kabupaten/Kota yang bertanggung jawab terhadap pembangunan kesehatan di wilayah kerjanya. Puskesmas berperan Menyelenggarakan upaya kesehatan untuk meningkstksn kesadaran, kemauan dan kemampuan hidup sehat bagi setiap penduduk agar memperoleh derajat kesehatan yang optimal. Dengan demikian Puskesmas berfungsi sebagai pusat bergerak pembangunan berwawasan kesehatan, pusat pemberdayaan keluarga dan masyarakat serta pusat pelayanan kesehatan strata pertama. UPTD Puskesmas Batanghari merupakan salah satu dari 34 puskesmas yang ada di kabupaten Lampung Timur, UPTD Puskesmas Batanghari terletak dibanarjoyo, ibukota kecamatan Batanghari. Berdasarkan PMK No.75 tahun 2014 tentang puskesmas bahwasanya puskesmas adalah fasilitas pelayanan kesehatan yang menyelenggarakan upaya kesehatan masyarakat (UKM) dan upaya kesehatan perorangan (UKP) tingkat pertama, dengan lebih mengutamakan upaya promotif dan preventif, untuk mencapai derjat kesehatan masyarakat yang setinggitingginya diwilayah kerjannya. Puskesmas Batanghari dalam menjalankan fungsinya telah melaksanakan semua upaya kesehatan masyarakat tingkat pertama (esensial dan pengembangan) dan upaya Kesehatan perorangan tingkat pertama. UKM pengembangan merupakan upaya masyarakat yang kegiatannya memerlukan upaya yang sifatnya inovatif dan atau bersifat ekstensifikasi dan intensifikasi pelayanan, di sesuaikan dengan prioritas masalah kesehatan kekhususan Wilayah kerja dan potensi sumber daya yang tersedia.
UKM esensial meliputi pelayanan promosi kesehatan, kesehatan lingkungan, KIA-KB, Gizi dan pencegahan dan pengendalian penyakit. Upaya kesehatan pengembangaan yang telah dilakukan antaara lain:

$\checkmark$ Pelayanan Laboratorium

$\checkmark$ Usaha Kesehatan Sekolah (UKS)

$\checkmark$ Upaya Kesehatan gigi da mulut

$\checkmark$ Kesehatan Usia Lanjut

$\checkmark$ Pembinaan Pengobatan Tradisional

$\checkmark$ Perawatan Kesehatan Masyarakat

$\checkmark$ Kesehatan Reproduksi Remaja

$\checkmark$ Kesehatan Olahraga

UKP Tingkat Pertama dilaksanakan dalam bentuk rawat jalan, rawat inap, pelayanan gawat darurat, pelayanan satu hari. UPTD

Puskesmas Batanghari Lampung Timur mulai dibangun pada tanggal 15 Agustus 1969 Menetapkan bahwa lokasi pembangunan di Jalan Merdeka Rt 06 Rw 03 Desa Banarjoyo Kecamatan Batanghari Lampung Timur sebagai lokasi paling tepat untuk didirikan Puskesmas. Dengan luas $\pm 43,32 \mathrm{~m}^{2}$. Pada tanggal 12 Januari 2018 membuka fasilitas Rawat Inap di Puskesmas Baranghari. Saat ini Kepala Puskesmas Batanghari ENDAR NURYANTO, S.K.M. Berkat kegigihan dan keuletan dari berbagai pihak saat ini Puskesmas Batanghari kini tetap siap melayani pasien. Pada UPTD Puskesmas Rawat Inap Batanghari yang mengkhususkan diri dalam pelayanan kesehatan masyarakat mengalami masalah yang sama diantaranya untuk pencatatan data-data pasien rawat inap dibuat dalam buku besar sehingga terjadi kesulitan dalam pencarian data pasien. Selain itu juga sering terjadi kesalahan dalam pencatatan data sehingga informasi yang dihasilkan tidak akurat. Untuk laporan yang diberikan kepada pimpinan pun menjadi tidak akurat sehingga terkadang membuat petugas puskesmas dan administrasi membutuhkan waktu lebih lama dalam mencari data-data pasien dan menyusun laporan untuk diserahkan pada pimpinan. Selain itu data-data yang telah dibuat seperti data pasien sewaktu-waktu dapat hilang atau rusak.karena masih dicatat dengan kertas, bisa saja kertas tersebut robek, atau terkena air dan dapat menimbulkan masalah dalam puskemas itu sendiri. 


\section{ЛIKI \\ 2. KAJIAN PUSTAKA DAN LANDASAN TEORI}

\section{A. Definisi Perancangan}

Menurut Utami Dewi Widianti (2012) Perancangan adalah: "Perancangan dapat didenifisikan sebagai penggambaran, perencanaan dan pembuatan sketsa atau pengaturan dari beberapa elemen yang terpisah ke dalam satu kesatuan yang utuh dan berfungsi. Tahapan ini menyangkut mengkonfigurasi dari komponen-komponen perangkat lunak dan perangkat keras dari suatu sistem sehingga setelah instalasi dari sistem akan benar-benar memuaskan dari rancang bangun yang telah ditetapkan pada akhir tahap analisis sistem". Definisi perancangan menurut George M. Scott pada buku yang berjudul Analisis dan Desain [2005:196]: "Perancangan merupakan desain sistem menentukan bagaimana suatu sistem akan menyelesaikan apa yang mesti diselesaikan, tahap ini menyangkut mengkonfigurasi dari komponen-komponen perangkat lunak dan perangkat keras dari suatu sistem sehingga setelah instalasi dari sistem akan benar-benar memuaskan rancang bangun yang telah ditetapkan pada akhir tahap analasis sistem".

Dari definisi diatas maka dapat diambil makna bahwa perancangan merupakan suatu tahapan untuk mendesain sistem baru yang didapat berdasarkan menganalisis masalah-masalah yang ada.

\section{B. Aplikasi}

Menurut Jogiyanto (2005:231) dalam buku analisis \& desain menyimpulkan bahwa: "perangkat lunak aplikasi (aplication software), yaitu progeam yang ditulis dan diterjemahkan oleh language software untuk menyelesaikan suatu aplikasi tertentu". Berdasarkan definisi di atas maka dapat diambil makna bahwa aplikasi adalah program yang siap digunakan yang dibuat untuk melakukan aktivitas atau pekerjaan tertentu yang saling terkait sehingga dapat memproses input menjadi output.

\section{Data}

Dalam kamus besar bahasa Inggris-Indonesia diterangkan bahwa, data diterjemahkan sebagai istilah yang berasal dari kata "datum" yang berarti fakta atau bahan -bahan keterangan. Menurut Sutarman (2009:3), dalam bukunya yang berjudul Pengantar Teknologi Informasi: "Fakta dari sesuatu pernyataan yang berasal dari kenyataan, di mana pernyataan tersebut merupakan hasil pengukuran atau pengamatan. Data dapat berupa angka-angka, huruf-huruf, simbol-simbol khusus, atau gabungan darinya. Data mentah masih belum bisa bercerita banyak sehingga perlu diolah lebih lanjut". Menurut Adi Nugroho (2011:5) dalam bukunya yang berjudul Sistem Basis Data "Data adalah fakta- fakta tentang segala sesuatu di dunia nyata yang dapat direkam dan disimpan dalam media komputer.Berdasarkan definisi-definisi di atas maka dapat diambil kesimpulan bahwa Data merupakan kumpulan kejadian yang diangkat dari suatu kenyataan atau (fakta) dapat berupa angka-angka, huruf, simbol-simbol khusus yang masih belum dapat bercerita banyak sehingga masih perlu diolah lebih lanjut.

\section{Pengolahan Data}

Menurut Sutarman (2005:9), dalam bukunya yang berjudul Pengantar Teknologi Informasi Menyebutkan bahwa "Pengolahan data adalah proses perhitungan /transformasi data input menjadi informasi yang mudah dimengerti ataupun susuai yang diinginkan". Menurut Jogiyanto (2005:9) pengolahan data merupakan: "Data yang dioleh melalui suatu model menjadi informasi, penerima kemudian menerima informasi tersebut, membuat suatu keputusan dan melakukan tindakan, yang berarti menghasilkan suatu tindakan yang lain akan membuat sejumlah data kembali,data tersebut akan ditangkap sebagai input, diproses kembali lewat suatu model dan seterusnya membentuk suatu siklus". Berdasarkan pendapat para ahli dapat diambil makna pengolahan data adalah suatu proses menerima dan mengeluarkan data menjadi bentuk lain berupa informasi. Operasi yang dilakukan dalam pengolahan data antara lain: 


\section{ЛIKI}

\section{E. Masukan data (Input)}

Tahap ini yang merupakan proses memasukan data kedalam proses komputer melalui alat input (input device)

\section{F. Proses (processing)}

Tahap ini yang merupakan proses pengolahan/pemrosesan dari data yang sudah dimasukan yang dilakukan oleh alat pemroses yang dapat berupa proses menghitung, membanding, mengklasifikasikan, mengurutkan dan mengendalikan.

\section{G. Keluaran (output)}

Tahap ini merupakan proses yang menghasilkan output dari hasil pengolahan data ke alat output (output device), yaitu berupa informasi. . Seperti pada gambar 2.1 dibawah ini menurut Sutarman (Pengantar Teknologi Informasi 2009:4)

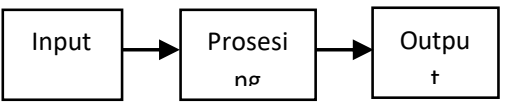

Gambar 2.1 Siklus Pengolahan Data

(Sumber : Rancangan Penulis Tahun 2018)

\section{H. Puskesmas}

Menurut Fiil Hendra Hasbi (2012) Puskesmas adalah:

"Pusat Kesehatan Masyarakat (Puskesmas) sebagai bagian dari sektor pelayanan publik (public sector) 1 ialah suatu unit pelaksana fungsional yang berfungsi sebagai pusat pembangunan kesehatan, pusat pembinaan peran serta masyarakat dalam bidang kesehatan serta pusat pelayanan kesehatan tingkat pertama yang menyelenggarakan kegiatannya secara menyeluruh, terpadu, dan berkesinambungan pada suatu masyarakat yang bertempat tinggal dalam suatu wilayah tertentu.

\section{Bahasa Pemograman (Java)}

Menurut Yusni Nyura (2010) Java adalah: Bahasa pemograman Object-Oriented dengan unsur-unsur seperti bahasa $\mathrm{C}++$ dan bahsabahasa lainnya yang memiliki libraries yang cocok untuk lingkungan internet. Java dapat melakukan pemograman, seperti membuat animasi halaman Web, pemograman Java untuk ponsel dan aplikasi interaktif. Java juga dapat di gunakan untuk handphone, internet dan lain-lain. Wahana komputer (2015:2) "java adalah: Bahasa pemograman yang dapat di jalankan diberbagai komputer maupun telepon genggam. Bahasa pemograman ini di buat oleh James Gosling saat ini masih bergabung di Sun Microsystems, dimana saat ini merupakan bagian dari oracle yang dirilis pada tahun 1995.

\section{J. Komponen Java}

Berikut tiga komponen penting yang dimiliki Java menurut Andi (2012:2), yaitu:

(1) The Java Programming Language adalah bahasa pemrograman yang digunakan untuk menulis kode program dalam platform java.

(2) The Java Platform adalah lingkungan yang digunakan untuk menjalankan kode program yang telah ditulis pada bahasa pemrograman java.

(3) The Java Application Program Interface adalah suatu kumpulan kelas-kelas dalam java yang digunakan untuk mengembangkan perangkat lunak berbasis GUI, penyimpanan data, serta pemrograman jaringan.

\section{K. Definisi Basis Data(Database)}

Berikut definisi basis data menurut para ahli antara lain: Simarmata (2010: 1) yang mengutip dari Rama krishnan dan Gehrke (2003) menyatakan "basis data sebagai kumpulan data, umumnya mendeskripsikan aktivitas satu organisasi atau lebih yang berhubungan".Simarmata (2010: 2) yang mengutip dari McLock, dkk., (2001) mendefinisikan "basisdata sebagai kumpulan seluruh sumber daya berbasis komputer milik organisasi". Dari definisi-definisi diatas dapat disimpulkan basis data adalah sekumpulan data yang saling berhubungan dalam bentuk yang 


\section{ЛIKI}

sedemikian rupa dan tanpa adanya pengulangan (redudansi).

\section{AppServ}

Adapun pengertian AppServ menurut Anggi Ariawan adalah software yang digunakan untuk database secara grafis/ gambar, software ini memudahkan para desain web dalam membuat database daripada cmd.exe yang penulisannya manual dan basis text. Berdasarkan pendapat diatas dapat ditarik kesimpulan Appserv adalah software basisdata, Mysql, pHp, phpMyadmin dilengkapi dengan server Apache.

\section{M. iReport}

Menurut Rohman (2017), Andi (2012:224) "iReport merupakan tool untuk pembuatan laporan yang paling populer dalam pemrograman java. Tool iReport ini hampir mirip dengan Crystal Report yang lebih populer dalam bahasa pemrograman yang lain". iReport merupakan aplikasi tunggal yang sudah terintregrasi dengan IDE NetBeans sehingga lebih mudah untuk memanfaatkan tool tersebut.

\section{METODE PENELITIAN}

Metodologi adalah kesatuan metode-metode, prosedur, konsep-konsep, pekerjaan atau aturan yang digunakan oleh suatu ilmu pengetahuan. Memperoleh data guna menyusun Tugas Akhir, penulis menggunakan metode-metode yaitu sebagai berikut :

\section{A. Studi Lapangan}

Studi lapangan adalah pengumpulan data dan informasi dari tempat penelitian, atas masalah yang sedang dihadapi. Adapun studi lapangan yang penulis lakukan adalah dengan teknik :

(1) Wawancara (Interview)

Interview adalah metode pengumpulan data dengan cara wawancara atau tanya jawab secara langsung dengan petugas Rawat Inap yang bersangkutan dengan ini penulis melakukan wawancara secara langsung dengan Ibu Nurhidayati selaku Staf Rawat Inap. Terlampir tabel wawancara.

(2) Pengamatan (Obsevasi)
Observasi adalah metode pengumpulan data dengan cara pengamatan langsung kegiatan operasional yang berlangsung di UPTD Puskesmas Batanghari Lampung Timur. Terlampir dokumentasi foto.

(3) Dokumentasi

Dokumentasi adalah metode pengumpulan data dengan cara mengambil gambar danmengumpulkan dokumen atau arsip yang dibutuhkan untuk penelitian. Terlampir dokumen-dokumen.

(4) Studi Pustaka

Metode yang dilakukan dengan mengambil bahan bacaan dari buku-buku yang berada pada perpustakaan kampus maupun di luar kampus yang berkaitan dengan tugas akhir.

(5) Waktu dan Tempat Penelitian

Penulis melakukan penelitian ini selama 2 bulan, yang dimulai dari tanggal 01 Maret 2018 sampai 03 Mei 2018, penelitian dilakukan di UPTD Puskesmas Batanghari Lampung Timur yang beralamatkan di Jalan Merdeka Rt 06 Rw 03 Desa Banarjoyo Kecamatan Batanghari Lampung Timur.

Adapun jadwal kegiatan penelitian dapat dilihat pada tabel 1.1

Tabel Jadwal Kegiatan Penelitian (Sumber: Penulis,tahun 2020)

\begin{tabular}{|c|c|c|c|c|c|c|c|c|c|}
\hline \multirow{3}{*}{ NO } & \multirow{3}{*}{ NAMA KEGIATAN } & \multicolumn{4}{|c|}{ MARET } & \multicolumn{4}{|c|}{ APRIL } \\
\hline & & \multicolumn{4}{|c|}{ Minggu ke } & \multicolumn{4}{|c|}{ Minggu ke } \\
\hline & & & 2 & 3 & 3 & 1 & 1 & 3 & 4 \\
\hline 1 & $\begin{array}{ll}\text { Survey } & \text { Tempat } \\
\text { Penelitian } & \end{array}$ & & & & & & & & \\
\hline 2 & $\begin{array}{ll}\text { Menganalisis } & \text { Sistem } \\
\text { Yang } & \text { Sedang } \\
\text { Berjalan } & \\
\end{array}$ & & & & & & & & \\
\hline 3 & $\begin{array}{l}\text { Merumuskan } \\
\text { Masalah }\end{array}$ & & & & & & & & \\
\hline 4 & Penyusunan Proposal & & & & & & & & \\
\hline 5 & Analisis Data & & & & & & & & \\
\hline 6 & Pengajuan Judul & & & & & & & & \\
\hline 7 & Pengumpulan Data & & & & & & & & \\
\hline
\end{tabular}

\section{HASIL DAN PEMBAHASAN}

\section{A. Hasil penelitian}




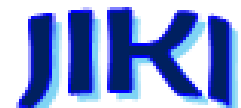

Pada UPTD Puskesmas Rawat Inap Batanghari yang mengkhususkan diri dalam pelayanan kesehatan masyarakat mengalami masalah yang sama diantaranya untuk pencatatan data-data pasien rawat inap dibuat dalam buku besar sehingga terjadi kesulitan dalam pencarian data pasien. Selain itu juga sering terjadi kesalahan dalam pencatatan data sehingga informasi yang dihasilkan tidak akurat. Untuk laporan yang diberikan kepada pimpinan pun menjadi tidak akurat sehingga terkadang membuat petugas puskesmas dan administrasi membutuhkan waktu lebih lama dalam mencari data-data pasien dan menyusun laporan untuk diserahkan pada pimpinan. Selain itu data-data yang telah dibuat seperti data pasien sewaktu-waktu dapat hilang atau rusak karena masih dicatat dengan kertas, bisa saja kertas tersebut robek, atau terkena air dan dapat menimbulkan masalah dalam puskemas itu sendiri.

\section{B. Gambaran Umum Sistem Yang Diusulkan}

Aplikasi yang diusulkan memiliki beberapa keunggulan dari sistem yang sedang berjalan. Sistem yang diusulkan lebih mudah digunakan. Lebih memperhemat waktu dalam proses pengolahan data Pasien yang tersimpan di database. Sehingga dapat mempermudah dalam proses pembuatan laporan. Pada tahapan perancangan prosedur ini bertujuan untuk menghasilkan perancangan aplikasi pengolahan data Pasien menggunakan database. Adapun perancangan proses ini mencakup aliran sistem informasi, diagram konteks, data flow diagram, flowchart, yang dapat menjelaskan aliran data yang diproses hingga menghasilkan informasi yang diinginkan. Aliran informasi yang diusulkan tidak merubah tujuan ataupun fungsi dari sistem informasi yang berjalan. Beberapa perubahan di dalam pengolahan data Pasien dilakukan untuk membuat sistem yang lebih baik. Berikut adalah aliran informasi yang diusulkan:

Aliran informasi pengolahan data pasien yang dimulai dari pasien mendaftar menyerahkan Kartu Pasien ke Bagian Petugas Rekam Medis lalu Bagian Rekam Medis mengecek data Pasien kemudian data pasien dicocokkan dengan Buku Rekam Medis. Setelah dicocokkan dengan Buku
Rekam Medis Pasien, kemudian Kartu pasien dikembalikan kepada Pasien, sedangkan Buku Rekam Medis diberikan kepada Ruangan Pemeriksa. Petugas Ruang Pemeriksa akan memeriksa dan mencatat keluhan atau penyakit pasien, jika pasien mengalami sakit yang cukup serius pasien di rawat lebih lanjut dan perawat mencarikan kamar untuk pasien. Kemudian Bagian Petugas Rekam Medis melakukan pengecekan pada buku besar Pasien yang akan dilaporkan kepada pihak Pimpinan. Untuk pembutan laporan dan peng Arsipan data pasien dilakukan oleh petugas Rekam Medis.

\section{a) Rancangan Diagram Konteks}

Diagram konteks adalah diagram yang terdiri dari suatu proses dan menggambarkan ruang lingkup suatu sistem. Rancangan menggambarkan diagram konteks pendaftaran pasien umum.

\section{1) Rancangan Diagram Konteks Level 0}

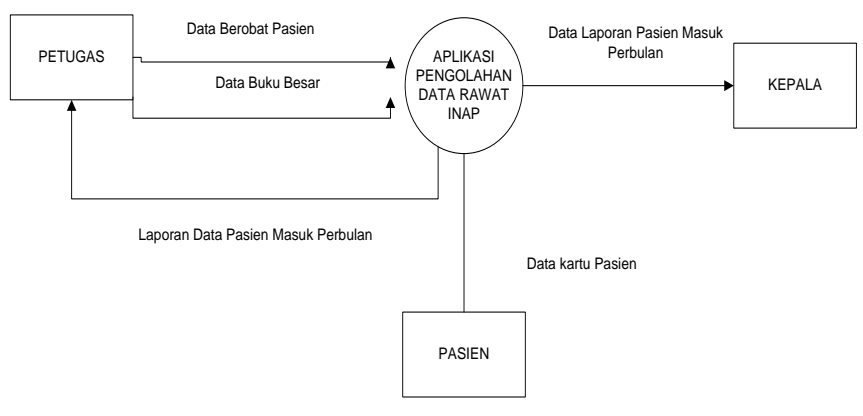

Gambar 4.1. Rancangan Diagram Konteks

(Sumber Penulis 2020)

\section{b) Rancangan Data Flow Diagram}

Data Flow Diagram (DFD) merupakan peralatan yang berfungsi untuk menggambarkan secara rinci mengenai sistem sebagai jaringan kerja antar fungsi yang berhubungan satu sama lain dengan menunjukkan dari dan kemana data mengalir serta penyimpanannya.

\section{2) Rancangan Data Flow Diagram (DFD) Level 1}




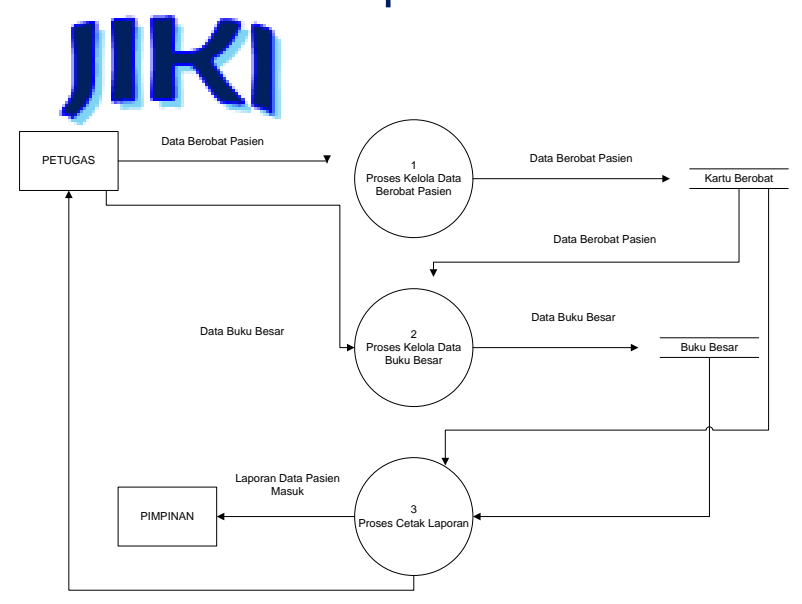

Gambar 4.2. Rancangan Data Flow Diagram (DFD) Level 1

(Sumber Penulis 2020)

menghasilkan struktur basisdata yang baik sehingga dapat disimpan dan diambil secara efisien.

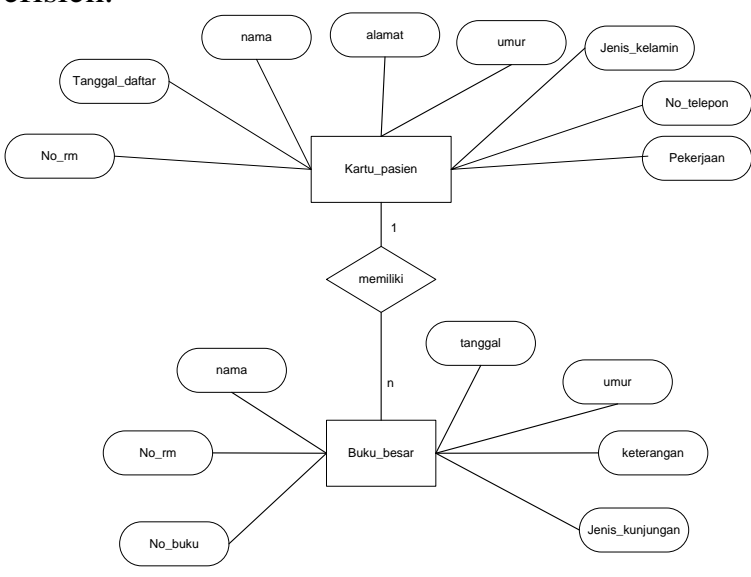

\section{c) Rancangan Flowchart}

Menurut Hartono (2005:795) mengatakan bahwabagan alir (Flowchart) adalah bagan (Chart) yang menunjukan alir (Flow) di dalam program atau prosedur sistem secara logika. Prosedur Pembuatan Kartu Berobat Pasien.

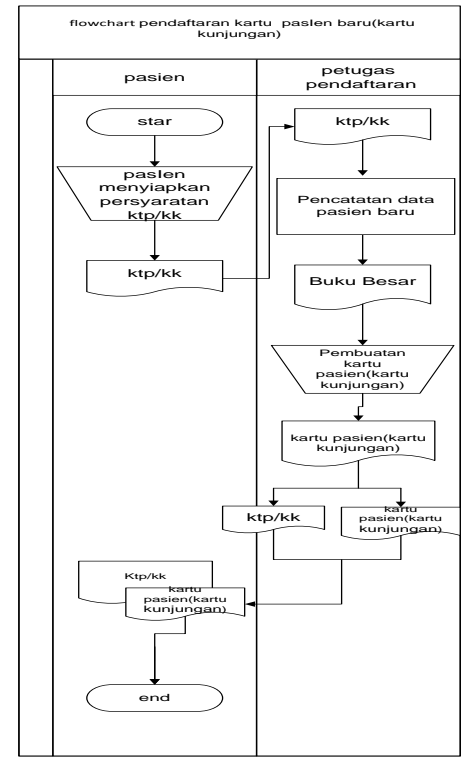

Gambar 4.4. Entity Relentionship Diagram (Sumber Penulis 2020)

\section{e) Relasi Tabel}

Hubungan antara tabel yang mempresentasikan hubungan antar objek di dunia nyata. Relasi merupakan hubungan yang terjadi pada suatu tabel dengan lainnya yang mempresentasikan hubungan antar objek di dunia nyata dan berfungsi untuk mengatur oprasi suatu database. Adapun rancangan database secara keseluruhan beserta relasinya dapat dilihat dibawah ini :

\begin{tabular}{|l|l|l|}
\hline \multicolumn{1}{|c|}{ Kartu_pasien } & \multicolumn{1}{c|}{ Buku_besar } \\
\hline * No_rm & & *No_buku \\
Tanggal_daftar & & No_rm \\
nama & & Tanggal_daftar \\
alamat & & umur \\
umur & No_telepon \\
Jenis_kelamin & alamat \\
No_telepon & keterangan \\
pekerjaan & Jenis_kunjungan \\
\hline
\end{tabular}

Gambar 4.3. Flowcart Prosedur Pembuatan Kartu Berobat Pasien (Sumber Penulis 2020)

\section{d) Entity Relationship Diagram (ERD)}

Entity Relentionship Diagram adalah alat pemodelan data utama dan akan membantu mengorganisasi data dalam satu proyek kedalam entitas-entitas dan menentukan hubungan antar entitas. Proses memungkinkan analis

Gambar 4.5. Gambar Relasi

(Sumber Penulis 2020)

Keterangan :

(*) : Primary Key

(**) : Foreign Key

\section{f) Perancangan Sistem Secara Terinci}

Rancangan Antar Muka Sistem 
JIKI

Rancangan Form Login Tampilan ini berfungsi sebagai tempat untuk memasukan username dan password ketika saat akan Login

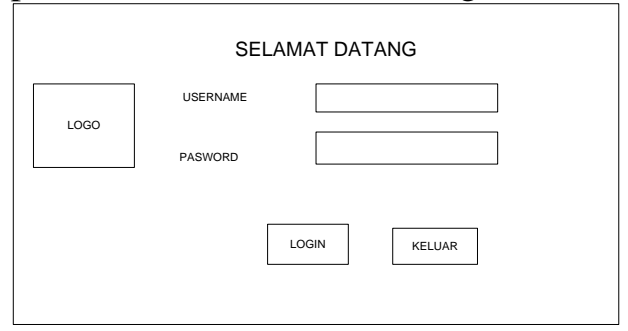

Gambar 4.6. Rancangan tampilan form Login

(Sumber Penulis 2020)

Penjelasan fungsi-fungsi tombol:

LOGIN : Tombol ini berfungsi untuk masuk menuju form menu atau aplikasi setelah mengisi nama dan password yang benar.

KELUAR : Tombol ini berfungsi untuk keluar dari form login.

\section{g) Rancangan Form Menu}

Tampilan ini berfungsi sebagai tempat untuk menampilkan form-form, Daftar Kartu Berobat, Buku Besar, cetak laporan.

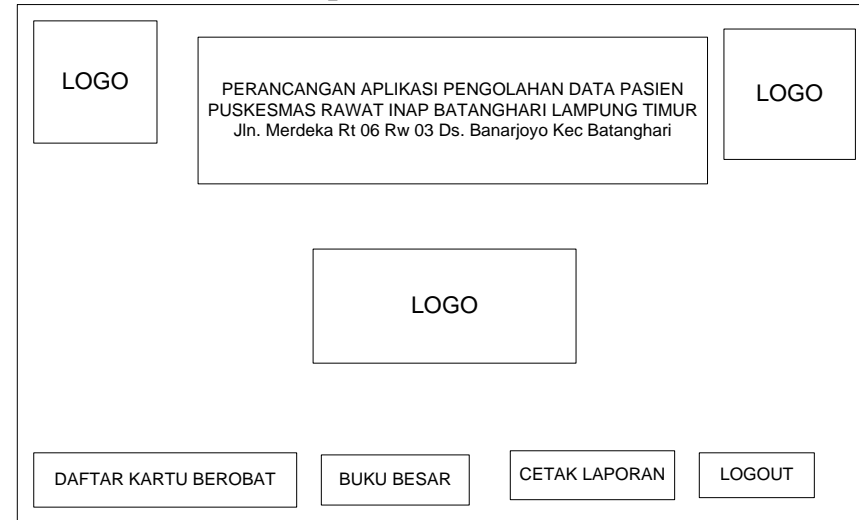

Gambar 4.7.

Rancangan tampilan form Menu Utama (Sumber Penulis 2020)

Penjelasan fungsi-fungsi tombol:

MENU DAFTAR KARTU BEROBAT: untuk mendaftarkan pasien yang belum pernah berobat
MENU BUKU BESAR : untuk mendaftarkan pasien yang sudah pernah berobat atau yang sudah memiliki kartu berobat

LOGOUT : untuk keluar dari From Menu Utama dan kembali ke form Login.

\section{h) Rancangan Form Kartu Berobat Pasien}

Tampilan ini berfungsi sebagai tempat untuk menampilkan From Kartu Berobat

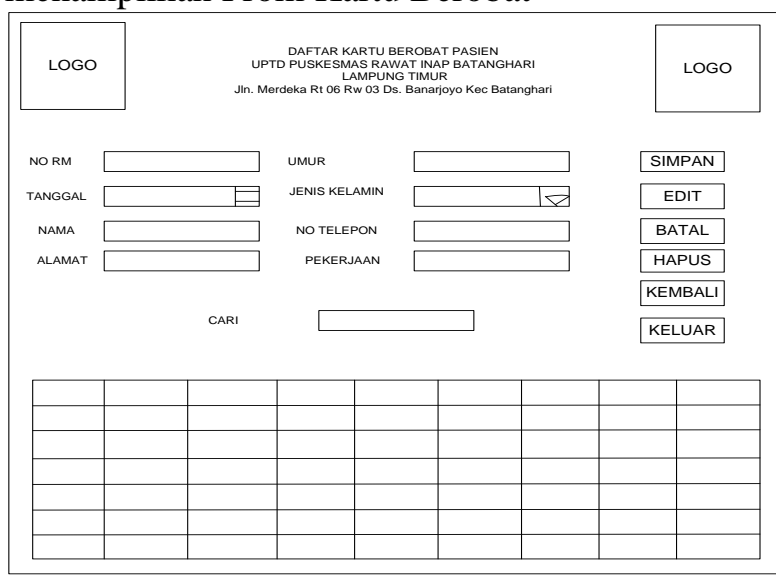

Gambar 4.8

Rancangan tampilan Form Kartu Berobat (Sumber Penulis 2020)

Penjelasan fungsi-fungsi tombol:

SIMPAN : untuk menyimpan data pasien yang telah di input

EDIT : untuk merubah data

BATAL :untuk membatalkan inputan

HAPUS : untuk menghapus data yg sudah di input.

KEMBALI : untuk kembali ke form menu utama

KELUAR : keluar dari form kartu berobat

\section{i) Rancangan Form Buku Besar}

Tampilan ini berfungsi sebagai tempat untuk menampilkan form Buku

Besar 
JIKI

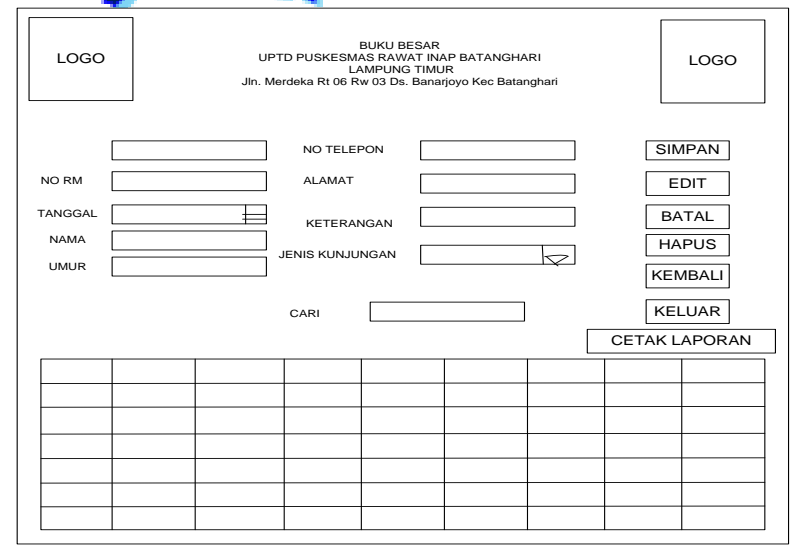

Gambar 4.9

Rancangan tampilan Form Kartu Berobat (Sumber Penulis 2020)

Penjelasan fungsi-fungsi tombol:

SIMPAN : untuk menyimpan data pasien yang telah di input

EDIT : untuk merubah data

BATAL :untuk membatalkan inputan

HAPUS : untuk menghapus data yg sudah di input.

KEMBALI : untuk kembali ke form menu utama

KELUAR : keluar dari form buku besar

CETAK LAPORAN : cetak laporan pada form buku besar menyangkut semua pasien.

PENCARIAN : Pencarian yaitu digunakan untuk mencari data pasien yang sudah pernah mendaftar atau yang sudah tersimpan

\section{j) Rancangan Cetak Laporan}

Tampilan ini berfungsi sebagai tempat untuk menampilkan From Cetak Laporan

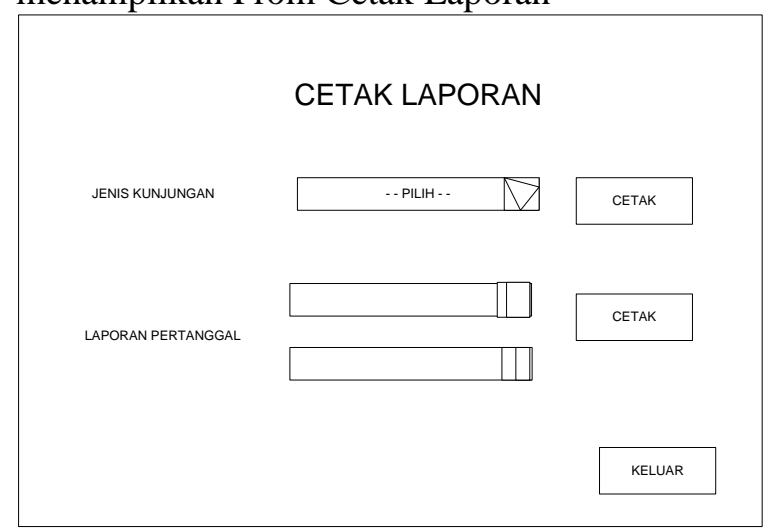

Gambar 4.10
Rancangan tampilan Form Cetak Laporan (Sumber Penulis 2020)

CETAK : tombol cetak untuk mencetak laporan pasien.

KELUAR : keluar dari form Cetak Laporan

\section{k) Pembahasan}

Pembahasan Form Login

Tampilan ini berfungsi sebagaai tempat untuk measukan username dan password ketika akan melakukan pendaftaran.

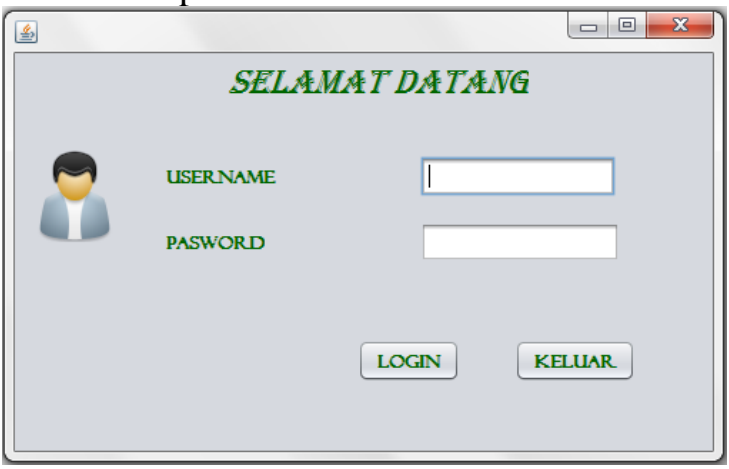

Gambar 4.11 Tampilan Form Login (Sumber Penulis 2020)

Form login menampilkan username dan pasword, admin harus memasukkan username dan pasword agar bisa masuk ke Menu utama.

\section{l) Pembahasan From Menu Utama}

Tampilan ini berfungsi sebagai tempat untuk masuk form-form data Pasien

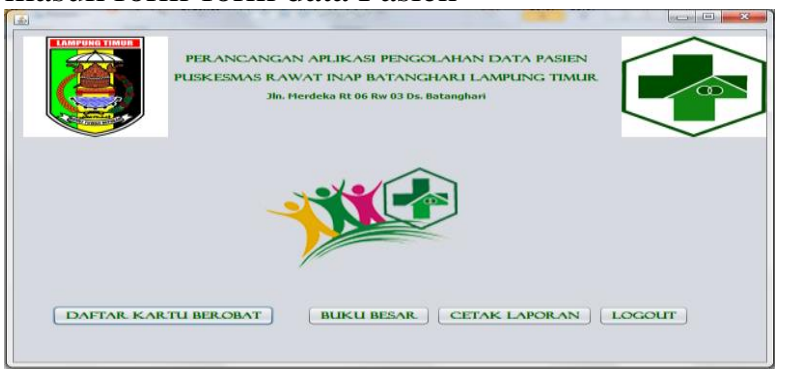

Gambar 4.12. Tampilan Form Menu Utama (Sumber Penulis 2020)

Form menu utama menampilkan daftar kartu pasien, buku besar, cetak laporan dan logout. Ketika admin klik tombol daftar kartu berobat 


\section{Jurnal Ilmu Komputer \& Informatika JIKI}

maka akan masuk ke form daftar kartu berobat, ketika admin klik tombol buku besar maka akan masuk ke form buu besar, dan ketika admin klik tombol cetak laporan maka akan masuk ke form cetak laporan.

\section{j) Pembahasan Form Kartu Berobat}

Tampilan ini berfungsi sebagai tempat untuk mendaftarkan pasien yang belum mempunyai kartu berobat

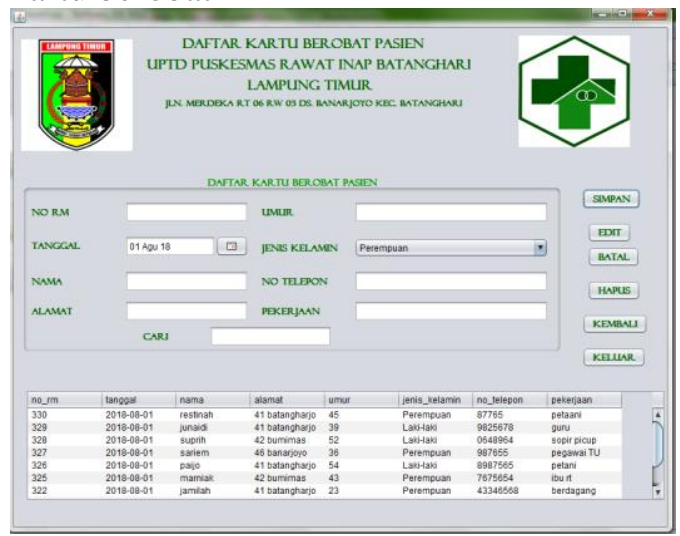

Gambar 4.13. Tampilan Form Kartu Berobat (Sumber Penulis 2020)

Pada form daftar kartu berobat ini berfungsi untuk pendaftaran pasien yang belum mempunyai kartu pasien, pasien harus menyerahkan ktp dan kartu keluarga.

\section{k) Pembahasan Form Buku Besar}

Tampilan ini berfungsi sebagai tempat untuk mendaftarkan pasien yang sudah mempunyai kartu berobat

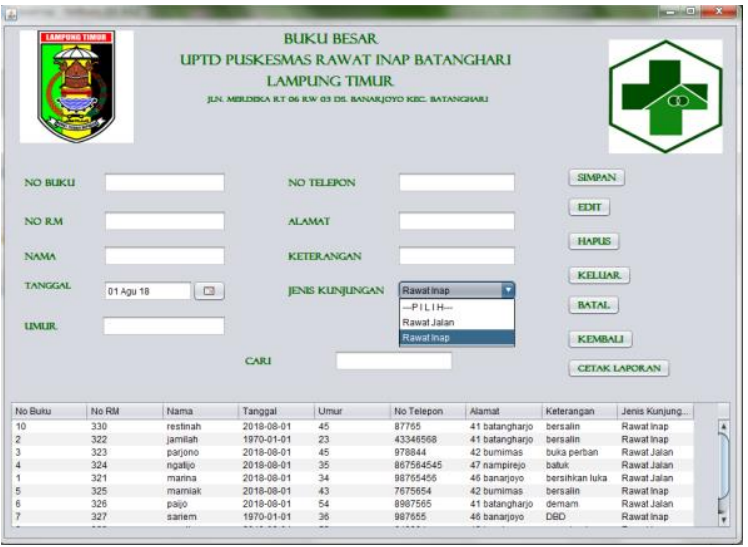

Gambar 4.14. Tampilan Form Buku Besar (Sumber Penulis 2020)
Pada form buku besar ini untuk penginputan pasien yang sudah mempunyai kartu pasien.

\section{1)Pembahasan Cetak Laporan}

Tampilan ini berfungsi sebagai laporan buku besar.

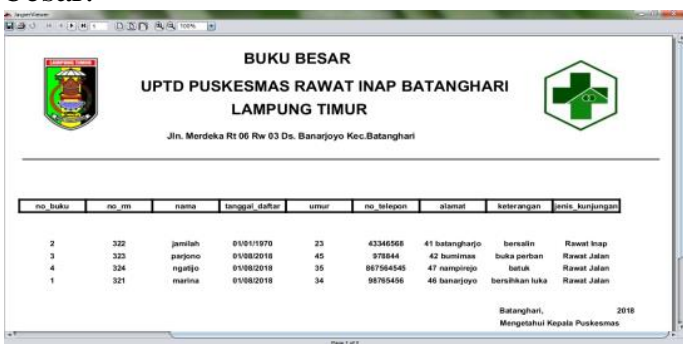

Gambar 4.15. Tampilan Cetak Laporan (Sumber Penulis 2020)

Cetak laporan buku besar ini berfungsi untuk mencetak laporan semua pasien.

Pembahasan form cetak laporan Tampilan ini berfungsi sebagai cetak laporan.

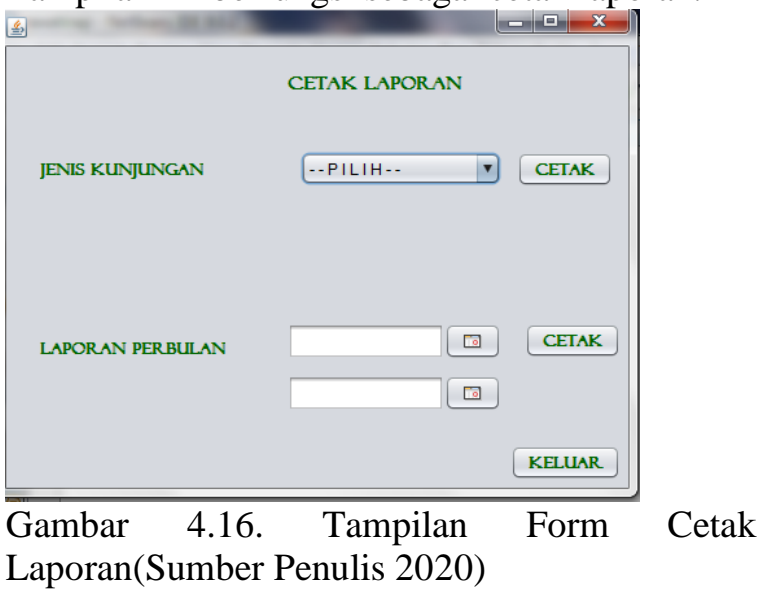

Form cetak laporan ini berfungsi untuk mencetak laporan jenis kunjungan yang di rawat inapkan dan rawat jalan.

\section{KESIMPULAN}

Setelah memahami dan menganalisa masalah yang terjadi maka penulis dapat merancang Aplikasi pengolahan data Rawat Inap menggunakan pemograman berbasis java pada UPTD Puskesmas Batanghari Lampung Timur.Sehingga dapat diambil beberapa kesimpulan sebagai berikut: 


\section{JIKI}

1. Aplikasi data Rawat Inap pada UPTD Puskesmas Batanghari di rancang dengan DFD, ERD dan di buat dengan pemrograman java disertai database MySQL.

2. Proses pencarian data pasien dibuat lebih mudah dengan menggunakan kunci pencarian berdasarkan No RM.

3. Laporan data pasien di buat untuk membantu meningkatkan efesiensi kerja petugas rekam medis saat proses pengolahan data Rawat Inap menggunakan pemograman berbasis java pada UPTD Puskesmas Batanghari Lampung.

\section{DAFTAR PUSTAKA}

Fiil, 2012. Analisis Hubungan Persepsi Pasien Tentang Mutu Pelayanan Dengan Pemanfaatan Ulang Pelayanan Rawat Jalan Puskesmas Poncol Kota Semarang. Jurnal kesehatan Masyarakat, Vol 1 No 2.37

Hartono, Jogianto. 2005. Analisis dan Desain. Yogyakarta: Andi Offset. Hudaya, Kharisma Kholid. 2015. Cara Cepat Menguasai Java Dekstop dengan Metode Pro-OOP. Yogyakarta. Andi.
Komputer, Wahana. 2015. Membangun Sistem Informasi dengan Java NetBeans dan MySQL. Semarang: Andi Nugroho, Adi. 2011. Sistem Basis Data. Yogyakarta: Andi

Nyura, Y. (2010). Pembuatan Aplikasi Pembelajaran Bahasa Inggris Pada Handphone dengan J2ME. Jurnal Informatika Mulawarman.

Riestiana, Meita Sistem Informasi Penggajian Karyawan Pada Commenditaire Vennontschap (CV) RGL Bordir Dan Konveksi Pacitan

Journal Speed - Sentra Penelitian Engineering dan Edukasi - Volume 6 No 4 - 2014 - ijns.org ISSN : 1979-9330 (Print) - 2088-0154 (Online) 31.

Simarmata, Janner dan Paryudi Imam. 2010. Basis Data. Yogyakarta. Andi

Utami. 2012.

Pembangunan Sistem Informasi Aset Di PT. Industri Telekomunikasi Indonesia (PERSERO) Berbasis web. Jurnal Ilmiah komputer dan informatika (KOMPUTA) . Vol 1 No 2.58. Utomo, Priyo. 2013. Cara Cepat dan Mudah Belajar Java Se7. Yogyakarta. Andi. Offset. 